\title{
Genetic polymorphisms and related risk factors of ischemic stroke in a Mongolian population in China
}

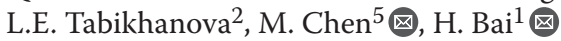 \\ ${ }^{1}$ Inner Mongolia University for the Nationalities, Tongliao, China \\ ${ }^{2}$ Institute of Cytology and Genetics SB RAS, Novosibirsk, Russia \\ ${ }^{3}$ Novosibirsk State University, Novosibirsk, Russia \\ ${ }^{4}$ Northern Virginia Community College, Virginia, USA \\ ${ }^{5}$ Department of Bioinformatics, College of Life Sciences, Zhejiang University, Hangzhou, China
}

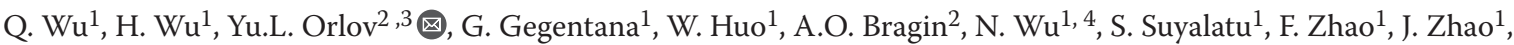

Ischemic stroke is caused by an interruption in the flow of blood to the brain and a risk factor for death and disability. Recent genome-wide association studies have identified more than 40 common sequence variants associated with ischemic stroke. However, the results are not always the same in populations with different genetic backgrounds. In the present study, we evaluated a hypothesis that a North Asian population living in a geographic area with unusually harsh environmental conditions would develop unique genetic risks. We investigated the candidate genes for ischemic stroke and risk factors in a Chinese Mongolian population which has not been explored previously. A total of 167 stroke cases and 176 controls were included in the study. Genotyping was performed by amplicon sequencing. The association was detected with single nucleotide polymorphisms (SNPs) located within genes NINJ2 (rs12425791) and ALDH2 (rs2238151) as well as intergenic rs9536591 were significantly associated with ischemic stroke, of which SNP rs12425791 of the NINJ2 gene was the strongest association. $A L D H 2$ gene encodes mitochondrial aldehyde dehydrogenase, involved in the oxidative pathway of alcohol metabolism. Sex, age, body mass index and high blood pressure might be the risk factors. The current work also demonstrated genetic heterogeneity exists between Chinese and other populations. Our study provided the new insights into the genetic basis and environmental factors of ischemic stroke in Mongolian population.

Key words: population genetics; human genome; SNPs; Chinese Mongolian population; ischemic stroke.

HOW TO CITE THIS ARTICLE:

Wu Q., Wu H., Orlov Yu.L., Gegentana G., Huo W., Bragin A.O., Wu N., Suyalatu S., Zhao F., Zhao J., Tabikhanova L.E., Chen M., Bai H. Genetic polymorphisms and related risk factors of ischemic stroke in a Mongolian population in China. Vavilovskii Zhurnal Genetiki i Selektsii $=$ Vavilov Journal of Genetics and Breeding. 2017:21(5):581-587. DOI 10.18699/VJ17.275

\section{Генетический полиморфизм и сопутствующие факторы риска ишемического инсульта в монгольской популяции Китая}

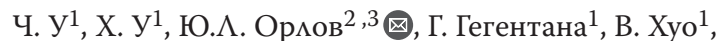 \\ А.О. Брагин ${ }^{2}$, Н. У1, ${ }^{1}$, С. Суямату ${ }^{1}$, Ф. Жао ${ }^{1}$, Ж. Жао ${ }^{1}$, \\ $\Lambda . Э$. Табиханова ${ }^{2}$, М. Чен ${ }^{5} \otimes$, Х. Бай ${ }^{1} \otimes$
}

\footnotetext{
${ }^{1}$ Национальный университет Внутренней Монголии, Тунляо, Китай

2 Федеральный исследовательский центр Институт цитологии и генетики Сибирского отделения Российской академии наук, Новосибирск, Россия

${ }^{3}$ Новосибирский государственный университет, Новосибирск, Россия

${ }^{4}$ Колледж Северной Вирджинии, Вирджиния, США

${ }^{5}$ Отдел биоинформатики, Колледж естественных наук, Университет Чжецзян, Ханчжоу, Китай
}

Ишемический инсульт, вызванный прерыванием потока крови в мозг, представляет серьезную медицинскую проблему, являясь фактором риска смерти и потери трудоспособности. Недавние исследования геномных ассоциаций (genome-wide association studies - GWAS) определили более 40 общих вариантов геномных последовательностей, связанных с ишемическим инсультом. Однако результаты не могут быть одинаково применимы для различных мировых популяций. В данной работе мы рассматриваем гипотезу о том, что население Северной Азии, живущее в суровых условиях окружающей среды, может иметь уникальный спектр генов риска развития заболеваний сердечно-сосудистой системы. Исследованы гены-кандидаты предрасположенности к ишемическому инсульту в популяции монголов Китая, которая не была изучена ранее. В исследование были включены в общей сложности 167 больных с инсультом и 176 здоровых лиц. Генотипирование выполнено с помощью секвенирования ампликонов. Обнаружена ассоциация развития ишемического инсульта с одиночными нуклеотидными полиморфизмами в генах NINJ2 (rs12425791) и ALDH2 (rs2238151), а также в межгенном участке rs9536591. Среди генов-кандидатов наибольший вклад в развитие инсульта вносит NINJ2 (rs12425791). Ген ALDH2 кодирует митохондриальный фермент альдегиддегидрогеназу, вовлеченную в оксидативный путь метаболизма алкоголя. Пол, возраст, индекс массы тела и высокое кровяное давление также могут быть факторами риска. Данная работа показала существующую гетерогенность между китайской и другими популяционными выборками. Наше исследование предлагает новый взгляд на взаимодействие генотипа и факторов окружающей среды при развитии ишемического инсульта в монгольском населении.

Ключевые слова: популяционная генетика; геном человека; однонуклеотидные замены; монгольская популяция Китая; ишемический инсульт. 
schemic stroke, accounts for about $80 \%$ of the stroke population (Dichgans, 2007; Mozaffarian et al., 2016), is a leading cause of mortality and morbidity and presents a serious and growing threat to public health (Krupinski et al., 1994; Lai et al., 1994). Ischemic stroke is a multi-factorial disorder (Hassan, Markus, 2000; Goldstein et al., 2006) associated closely with conventional vascular risk factors and genetic factors which have been accepted as important risk contributors to the development of ischemic stroke (Dichgans, 2007). Animal and epidemiological study has indicated that ischemic stroke has obvious genetic predisposition (Hassan, Markus, 2000).

With the advances of study on ischemic stroke, many susceptibility genes related to stroke have been identified using candidate gene association studies and genome-wide association studies (GWAS) (Matar et al., 2007; Ding et al., 2011; Wan et al., 2011; Bellenguez et al., 2012). The most susceptibility genes for ischemic stroke mainly are related with lipid metabolism, inflammation, renin-angiotensin-aldosterone system, homocysteine metabolism, nitric oxide synthase, and heart disease (Hassan, Markus, 2000; Lindsberg, Grau, 2003; Rubattu et al., 2004; Komitopoulou et al., 2006; Adibhatla, Hatcher, 2008). Besides, numerous potential factors attribute to the development of ischemic stroke, such as age (Wolf et al., 1992; Brown et al., 1996), sex (Brown et al., 1996; Sacco et al., 1998), low birth weight (Barker, Lackland, 2003), race (Gorelick, 1998; Sacco et al., 1998; Wan et al., 2011).

However, the assessing the susceptibility genes remains problematic. This is in part limited by the number of approaches currently available (Hassan, Markus, 2000). And, the ischemic stroke is a polygenic disease with a number of different phenotypes which have different genetic profiles (Hassan, Markus, 2000). Therefore, it is necessary for the discovery of new susceptibility loci in different ethnic groups. The problem of ethnic background predisposition to human diseases including type 2 diabetes is widely discussed (Bai et al., 2015; Nabodita, Sher, 2016; Tiis et al., 2016).

To provide new insights in clinical diagnosis and therapy, the aim of present study was to test 15 candidate SNPs of ischemic stroke and explore genetic risks of ischemic stroke in a relatively large Mongolian ethnicity.

\section{Methods}

Ethics Statement. This study was approved by the Institutional Review Board of the Affiliated hospital of Inner Mongolia University for the Nationalities and complied with the Declaration of Helsinki. The written informed consent was obtained from each participant.

Study participants. The subjects included 343 individuals of Chinese Mongolian ethnicity, of whom 167 were patients affected with ischemic stroke at various stages of the disease and 176 were normal controls. Control individuals were not related to the ischemic stroke patients or each other. Nonstroke, healthy, non-relatives persons were selected as control group from the same region.

Peripheral blood samples from all participants were collected into heparinized tubes. Body mass index (BMI), systolic blood pressure (SBP), diastolic blood pressure (DBP), total cholesterol (TC), triglyceride (TG), high density lipoprotein cholesterol (HDL-C) and low density lipoprotein cholesterol (LDL-C) were measured at the same time for all partici- pants (Table 1). The significance tests were performed to evaluate the case-control difference in sex, age and seven clinical parameters. Population attributable risks were evaluated by dividing the individuals into 5 groups: $30-39$ years, $40-49$ years, 50-59 years, 60-69 years and above 70 years old. Sex, age, BMI, high blood pressure (HBP) were selected as risk factors for ischemic stroke. The associations between the risk factors with ischemic stroke were tested using logistic regression.

A multivariate unconditional logistic regression model was employed to analyze the high risk factors of ischemic stroke.

Selection of SNPs. We selected a list of SNPs previously found to be associated with ischemic stroke based on NHGRI GWAS catalog (www.genome.gov/gwastudies, http://www. ebi.ac.uk/gwas/). Candidate SNPs were initially selected with the following considerations: (1) SNPs found to be associated with ischemic stroke in an Asian sample were given higher priority; and (2) subsequently SNPs found to be associated with multiple studies were included. We were able to genotype 15 SNPs located in or near 15 candidate genes.

DNA extraction and sequencing. DNA was extracted from all peripheral blood samples. We estimated the concentration of isolated genomic DNA using Qubit dsDNA BR Assay Kit (Invitrogen, USA), and the DNA solution was further diluted to a concentration of $10 \mathrm{ng} / \mu \mathrm{L}$. We designed the targeted sequencing primers and redesigned the primer sets with dispersed or weak electrophoretic bands. To prepare the chip array, we used a multisample nanodispenser (WaferGen, USA) to disperse DNA and primers into SmartChip MyDesign Chip (WaferGen, USA). Following the polymerase chain reaction (PCR) amplification, we purified PCR products through Agencourt AMPure XP-medium beads to get mixed Illumina pair-end libraries. Insert sizes were calculated by Agilent 2100 bioanalyzer (Agilent, USA) and concentrations were estimated by Real Time PCR. Sequencing was performed on either Illumina MiSeq. All sequencing steps were in strict accordance with Illumina recommended protocols.

Data processing and statistical analysis. In brief, the final sequencing depth reached $>200 x$, and the length of pair-end reads was $100 \mathrm{bp}$. Reads with an average base quality of $\geq 20$ were kept for further analysis, that corresponds to common practice of sequencing data analysis (Orlov, 2014; Ignatieva et al., 2015). After filtering, we carried out assembly using Burrows-Wheeler Aligner (version 0.5.9) (Li, Durbin, 2009) to map all clean reads against the human reference genome of hg19 allowing $\leq 3$ mismatches across a single read.

Samtools mpileup (version 0.1.18) (Li et al., 2009) command was used to obtain SNP genotypes. These genotypes were further filtered according to the following criteria: SNPs with $\geq 5 \%$ of missing call rate across the samples. Samples with $\geq 3 \%$ of missing genotypes (which corresponds to $10 \%$ of missing SNP call rate) were removed. We tested SNPs for Hardy-Weinberg Equilibrium (HWE) and excluded SNPs using the criterion (Shi et al., 2009; Muglia et al., 2010): HWE $P$ value $<1 \cdot 10^{-6}$ in unaffected individuals. Fifteen SNPs of 343 samples (167 cases and 176 controls) passed the quality control filtering, and the overall genotype call rate is $99.3 \%$ or higher across the sample.

We tested association between candidate SNPs and the status of ischemic stroke using logistic regression (likelihood ratio test) by adjusting for the effects of age, sex, BMI, 
Table 1. Variables and assignment

\begin{tabular}{|c|c|c|}
\hline \multirow[t]{2}{*}{ Variable } & \multicolumn{2}{|l|}{ Assigning } \\
\hline & Male & Female \\
\hline Age, years & Continuous variable & Continuous variable \\
\hline $\mathrm{BMI}, \mathrm{kg} / \mathrm{m}^{2}$ & $<28=0$ & $\geq 28=1$ \\
\hline $\mathrm{HBP}, \mathrm{mmHg}$ & $\mathrm{SBP}<140$ or $\mathrm{DBP}<90.0$ & $\mathrm{SBP} \geq 140$ or $\mathrm{DBP} \geq 90.1$ \\
\hline $\mathrm{TC}, \mathrm{mmol} / \mathrm{L}$ & Continuous variable & Continuous variable \\
\hline $\mathrm{TG}, \mathrm{mmol} / \mathrm{L}$ & $»$ & $»$ \\
\hline $\mathrm{HDL}-\mathrm{C}, \mathrm{mmol} / \mathrm{L}$ & $»$ & $»$ \\
\hline LDL-C, mmol/L & $»$ & $»$ \\
\hline
\end{tabular}

Note: Using the cutting standard of obesity in Chinese patients: $\mathrm{BMI} \geq 28 \mathrm{~kg} / \mathrm{m}^{2}$, Male's waist $\geq 90 \mathrm{~cm}$, Female's waist $\geq 85 \mathrm{~cm}$.
Table 2. Clinical characteristics of Mongolian population

\begin{tabular}{cccc} 
Characteristics & Controls & Cases & $P$-value \\
\hdashline Samples, $n$ & 176 & 167 & \\
\hdashline Sex (Male/Female) & $49 / 127$ & $96 / 71$ & 0.000 \\
\hdashline Age, years & $50.99 \pm 12.07$ & $57.50 \pm 9.28$ & 0.000 \\
\hdashline BMI, kg/m & $25.35 \pm 4.61$ & $27.45 \pm 4.61$ & 0.000 \\
\hline SBP, $\mathrm{mmHg}$ & $120.55 \pm 20.08$ & $158.90 \pm 35.70$ & 0.000 \\
\hline DBP, $\mathrm{mmHg}$ & $86.74 \pm 23.17$ & $103.20 \pm 23.83$ & 0.000 \\
\hdashline TC, $\mathrm{mmol} / \mathrm{L}$ & $7.97 \pm 35.27$ & $5.11 \pm 1.09$ & 0.296 \\
\hdashline TG, $\mathrm{mmol} / \mathrm{L}$ & $2.24 \pm 1.86$ & $2.13 \pm 1.53$ & 0.563 \\
\hline HDL-C, $\mathrm{mmol} / \mathrm{L}$ & $1.45 \pm 0.39$ & $1.39 \pm 1.51$ & 0.621 \\
\hline LDL-C, $\mathrm{mmol} / \mathrm{L}$ & $3.08 \pm 0.80$ & $3.08 \pm 0.88$ & 0.963 \\
\hline
\end{tabular}

Note: Values for continuous variables denote mean \pm standard error of mean (SEM).
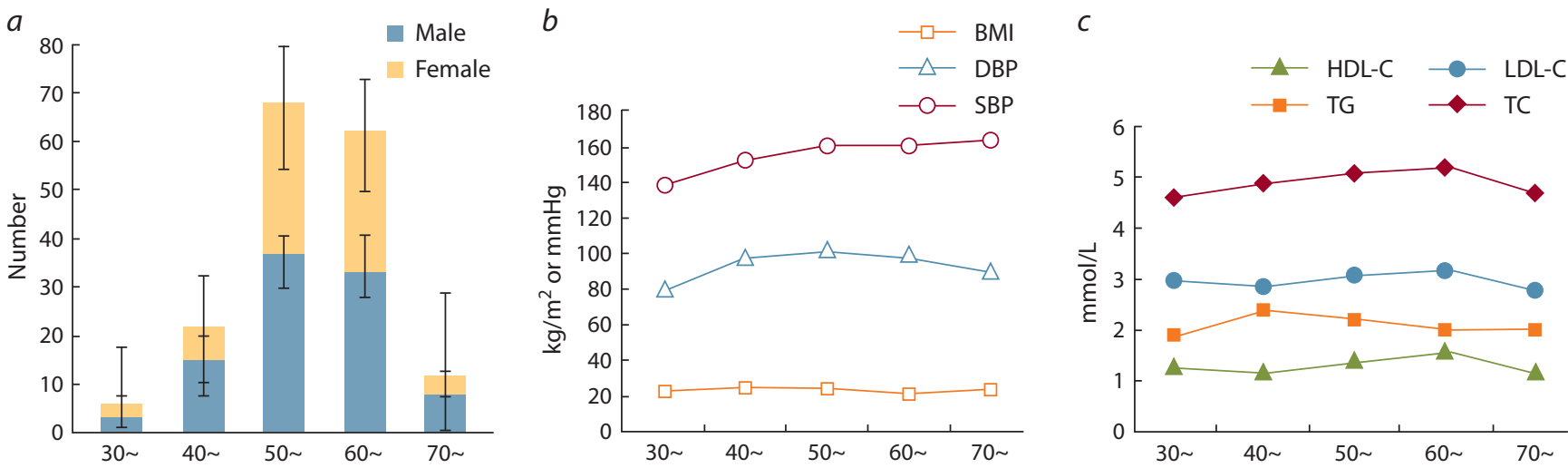

Age specific means and standard errors for index in a studied sample.

$a$, distribution of patients by age in the samples; $b$, distribution of BMI, SBP, DBP by age in the samples; $c$, distribution of TC, TG, HDL-C and LDL-C by age in the samples.

Table 3. Multivariate logistic regression analysis

\begin{tabular}{|c|c|c|c|c|c|c|}
\hline Variable & B & SE & Wald & $P$-value & OR & $95 \% \mathrm{Cl}$ \\
\hline Sex & -0.980 & 0.27 & 13.51 & $2.37 \mathrm{E}-04$ & 0.38 & $0.22-0.63$ \\
\hline Age & 0.050 & 0.01 & 11.88 & $5.67 \mathrm{E}-04$ & 1.05 & $1.02-1.07$ \\
\hline BMI & 0.900 & 0.28 & 10.18 & $1.42 \mathrm{E}-03$ & 2.45 & $1.41-4.25$ \\
\hline HBP & 1.950 & 0.3 & 43.43 & $4.39 \mathrm{E}-11$ & 7.05 & $3.95-12.61$ \\
\hline
\end{tabular}

SBP and DBP. We tested association with diabetes related quantitative traits (TC, HDL-C, LDL-C, and TG) across both ischemic stroke cases and controls using linear regression with the age, sex, BMI, and ischemic stroke status as covariates. All quantitative trait measures were normalized by quantile normalization and the normalized values were used in the analyses. Formal statistical tests, including $95 \%$ confidence intervals (CI), were performed using SPSS 13.0.

Differences in population structure between the healthy and control sample were estimated by comparing risk allele frequency and the Wright's fixation index (FST) using plink.

\section{Results}

After rigorous sample and marker level quality control filtering, genotypes of 15 SNPs on 343 individuals (including with 167 ischemic stroke cases and 176 stroke ethnically matched controls) were kept for subsequent analyses. Clinical characteristics of the sample are summarized in Table 2. Sex, age, BMI, SBP and DBP were significant difference between patients and normal (Table 2, Figure). Results of this study suggested that age, high blood pressure (HBP) are major risk factors for ischemic stroke in Chinese Mongolian population (Table 3 ). Table 4 presents the association results 
Table 4. SNPs significantly associated with Chinese Mongolian

\begin{tabular}{|c|c|c|c|c|c|c|c|c|}
\hline \multirow[t]{2}{*}{ Chr } & \multirow[t]{2}{*}{ Gene } & \multirow[t]{2}{*}{ SNP } & \multirow{2}{*}{$\begin{array}{l}\text { Minor } \\
\text { allele }\end{array}$} & \multicolumn{2}{|l|}{ MAF } & \multirow[t]{2}{*}{ OR } & \multirow[t]{2}{*}{$95 \% \mathrm{Cl}$} & \multirow{2}{*}{$\begin{array}{l}P \text {-value (adjusted } \\
\text { for age, sex, BMI) }\end{array}$} \\
\hline & & & & Cases & Controls & & & \\
\hline 3 & SPSB4 & rs16851055 & A & 0.126 & 0.128 & 0.84 & $0.52-1.36$ & 0.4780 \\
\hline 4 & $N R$ & rs2200733 & $\mathrm{T}$ & 0.473 & 0.446 & 1.06 & $0.75-1.50$ & 0.7525 \\
\hline 4 & PITX2 & rs6843082 & A & 0.27 & 0.335 & 0.76 & $0.51-1.15$ & 0.1980 \\
\hline 5 & ADAMTS12 & rs1364044 & $\mathrm{T}$ & 0.422 & 0.421 & 1.06 & $0.74-1.54$ & 0.7406 \\
\hline 5 & ADAMTS2 & rs469568 & $\mathrm{C}$ & 0.174 & 0.114 & 1.53 & $0.99-2.36$ & 0.0570 \\
\hline 6 & $C D C 5 L$ & rs556621 & $\mathrm{T}$ & 0.434 & 0.443 & 0.59 & $0.42-0.84$ & 0.0036 \\
\hline 6 & AIM1 & rs783396 & A & 0.054 & 0.08 & 0.79 & $0.39-1.57$ & 0.4994 \\
\hline 7 & Intergenic & rs10486776 & A & 0.057 & 0.071 & 0.79 & $0.41-1.53$ & 0.4824 \\
\hline 7 & HDAC9 & rs2107595 & A & 0.225 & 0.335 & 0.57 & $0.41-0.81$ & 0.0018 \\
\hline 11 & TRIM29 & rs2084898 & A & 0.018 & 0.026 & 0.78 & $0.25-2.46$ & 0.6773 \\
\hline 12 & NINJ2 & rs12425791 & A & 0.374 & 0.27 & 1.83 & $1.21-2.77$ & 0.0044 \\
\hline 12 & $A L D H 2$ & rs2238151 & $\mathrm{T}$ & 0.189 & 0.139 & 1.74 & $1.09-2.79$ & 0.0208 \\
\hline 13 & Intergenic & rs9536591 & A & 0.407 & 0.315 & 1.52 & $1.08-2.15$ & 0.0162 \\
\hline 16 & ZFHX3 & rs879324 & A & 0.293 & 0.341 & 0.72 & $0.48-1.07$ & 0.0991 \\
\hline 18 & IMPA2 & rs7506045 & $\mathrm{T}$ & 0.27 & 0.21 & 1.22 & $0.85-1.77$ & 0.2830 \\
\hline
\end{tabular}

Note: Chr, chromosome; MAF, minor allele frequency; listed $P$-values, odds ratios and $95 \%$ confidence intervals were calculated using the additive model of genetic association.

between the 15 SNPs and ischemic stroke status. Of the 15 SNPs tested, SNPs located within NINJ2 (rs12425791, $\left.P=4.4 \cdot 10^{-3}, \mathrm{OR}=1.83,95 \% \mathrm{CI}=1.21-2.77\right), A L D H 2$ $\left(\mathrm{rs} 2238151, P=2.08 \cdot 10^{-2}, \mathrm{OR}=1.74,95 \% \mathrm{CI}=1.09-2.79\right)$ and intergenic SNP (rs9536591, $P=1.62 \cdot 10^{-2}, \mathrm{OR}=1.52$, $95 \%$ CI $=1.08-2.15)$ were significantly associated with ischemic stroke risks (Table 4), of which SNP rs12425791 of the NINJ2 gene is the strongest association.

\section{Discussion}

Environmental factors may increase the risk of ischemic stroke (Huriletemuer et al., 2010), including age and gender and body mass index. We randomly surveyed 167 Mongolian patients with ischemic stroke years. The minimum age of these patients is 32 years old, and 50-60 years of age old group had more patients with ischemic stroke than other groups (Figure). Previous studies showed that the risk of stroke increased along with increasing age (Wolf et al., 1992; Brown et al., 1996; Goldstein et al., 2006). However, the age did show it was a risk factor of ischemic stroke according to the logistic regression analysis in Mongolian population. Traditionally, the weight status is classified according to body mass index. Persons with a BMI of 24 to 28 are classified as being overweight, and those with a BMI of $\geq 28 \mathrm{~kg} / \mathrm{m}^{2}$ are classified as being obese based on the Chinese obesity standard (Wang et al., 2007). Some large-scale prospective studies showed that increased weight is associated stroke in a dose-response fashion (Rexrode et al., 1997; Kurth et al., 2002; Song et al., 2004). Our study showed that gender and obesity might be a risk factor for ischemic stroke in Chinese Mongolian population. The main diet of Mongolian population is meat and dairy products. Meanwhile, our study showed the high cholesterol level was present between 50 to 60 years old of Mongolian, and high levels of TG were common in all ages. This might lead to obesity in Mongolian population and increase the risk for ischemic stroke. As a major risk factor of cerebral infarction and intracerebral hemorrhage (Izzo et al., 2003; Fields et al., 2004), hypertension contributes to the attack of stroke (Lewington et al., 2002). Along with the increasing age, blood pressure increase also (Burt et al., 1995). The control of blood pressure is an effective method for prevention of outbreak, development and cure of ischemic stroke (Black et al., 2001; Whelton et al., 2002; Ong et al., 2007). Based on our analysis, the typical clinical features of patients with ischemic stroke have obvious high blood pressure in Mongolian population, further prompt the Chinese Mongolian stroke may be caused by accelerated atherosclerosis.

Several studies have evaluated the association between rs12425791 and risk of ischemic stroke, but the results remain controversial. SNPs rs 12425791 locates on chromosome 12p13, close to NINJ2 gene which encodes ninjurin-2 protein. Ninjurin-2 protein, also named nerve injury-induced protein, is induced expression by nerve injury in Schwann cells (Araki, Milbrandt, 2000). The GWAS analyses showed that rs12425791 is associated with an increased risk of stroke for black and Dutch population (Ikram et al., 2009) and Asian population (Li et al., 2012; Lian et al., 2012). However, rs12425791 didn't show association with ischemic stroke in European ancestry. Previous studies showed that rs12425791 is relative to ischemic stroke risk in Asian population (Lian et al., 2012; Zhang et al., 2016). However, the contradictory studies about association between rs 12425791 or NINJ2 gene and ischemic stroke also emerge in Chinese Han population (Chen et al., 2010; Ding et al., 2011; Tong et al., 2011; Wan 
et al., 2011; Gu et al., 2013; Xie et al., 2013). In our study, we found variants rs 12425791 of the NINJ2 gene to be strongest associated with ischemic stroke in Chinese Mongolian ethnicity, and A alleles increase the risk of ischemic stroke, indicating the rs 12425791 of the NINJ2 gene might play function in the insult of ischemic stroke.

$A L D H 2$ gene locates in chromosome 12q24.2 and encodes mitochondrial aldehyde dehydrogenase (ALDH-E2). ALDHE2 involves in the oxidative pathway of alcohol metabolism (Smith, 1986; Hempel et al., 1987). Substantial evidence indicated that alcohol abuse is sever risk factor for stroke (Gill et al., 1986, 1991; Hillbom et al., 1999; Klatsky et al., 2001; Mazzaglia et al., 2001). ALDH2 polymorphisms play a pivotal role on hypertension (Hasi et al., 2011; Wang et al., 2013; Yokoyama et al., 2013; Hu et al., 2014), heart disease (Gu, Li, 2014; Mizuno et al., 2015) and stroke (Yao et al., 2011; Lai et al., 2012). The single base mutation ( $A L D H 2 * 2)$ of $A L D H 2$, the predominant allele in East Asian populations (around $70 \%$ ) (Chen, Yin, 2008), is responsible for acute alcohol-flushing reaction in Asians (Crabb, 1990). Indeed, Mongolian drinks more than other ethnic groups in China (Cochrane et al., 2003). In the present study, SNP rs2238151 of $A L D H 2$ gene was associated with ischemic stroke in Chinese Mongolian population, indicating rs2238151 take action in ischemic stroke by alcohol metabolism.

In conclusion, we identified SNP rs2238151 of ALDH2 gene and rs12425791 of NINJ2 gene associated with ischemic stroke risk in the Chinese Mongolian population. Our discovery also demonstrated genetic heterogeneity exists between Chinese and other populations. Meanwhile, this study has limitations, we had limited power to detect associations with small effect sizes and associations with rare variants.

The studies of genes associated with the human deceases such as predisposition to alcohol have been started at the Institute of Cytology and Genetics SB RAS earlier on animal models (Morozova, Popova, 2010). Such problems of computer modeling in animal genetics were discussed at BGRS $\backslash$ SB-2016 conference (Orlov et al., 2016) that continue series of collaborative works between the authors from China and Russia (Bai et al., 2015).

\section{Acknowledgments}

We thank our study individuals for their generous participation in this study. Authors are grateful to L.P. Osipova and V.N. Babenko for science discussion. This study was supported by the National Natural Science Foundation of China (81060098 and 31402106), NSFC-RFBR Cooperation and Exchange Projects (81511130050 and RFBR), Scientific Research Project of Inner Mongolia University for Nationalities (NMD1321) and Science and Technology Program Project of Inner Mongolia Autonomous Region (YY150002). Work by YLO, AOB and LET was supported by ICG SB RAS budget project 03242016-0003 and RFBR project 15-54-53091.

\section{References}

Adibhatla R.M., Hatcher J. Altered lipid metabolism in brain injury and disorders. Subcell Biochem. 2008;49:241-268. DOI 10.1007/978-14020-8831-5_9.

Araki T., Milbrandt J. Ninjurin2, a novel homophilic adhesion molecule, is expressed in mature sensory and enteric neurons and promotes neurite outgrowth. J. Neurosci. 2000;20(1):187-195.
Bai H., Liu H., Suyalatu S., Guo X., Chu S., Chen Y., Lan T., Borjigin B., Orlov Y.L., Posukh O.L., Yang X., Guilan G., Osipova L.P., Wu Q., Narisu N. Association analysis of genetic variants with type 2 diabetes in a Mongolian population in China. J. Diabetes Res. 2015;613236. DOI 10.1155/2015/613236.

Barker D.J., Lackland D.T. Prenatal influences on stroke mortality in England and Wales. Stroke. 2003;34(7):1598-1602.

Bellenguez C., Bevan S., Gschwendtner A., Spencer C.C., Burgess A.I., Pirinen M., Jackson C.A., Traylor M., Strange A., Su Z., Band G., Syme P.D., Malik R., Pera J., Norrving B., Lemmens R., Freeman C., Schanz R., James T., Poole D., Murphy L., Segal H., Cortellini L., Cheng Y.C., Woo D., Nalls M.A., Müller-Myhsok B., Meisinger C., Seedorf U., Ross-Adams H., Boonen S., WlochKopec D., Valant V., Slark J., Furie K., Delavaran H., Langford C., Deloukas P., Edkins S., Hunt S., Gray E., Dronov S., Peltonen L., Gretarsdottir S., Thorleifsson G., Thorsteinsdottir U., Stefansson K., Boncoraglio G.B., Parati E.A., Attia J., Holliday E., Levi C., Franzosi M.G., Goel A., Helgadottir A., Blackwell J.M., Bramon E., Brown M.A., Casas J.P., Corvin A., Duncanson A., Jankowski J., Mathew C.G., Palmer C.N., Plomin R., Rautanen A., Sawcer S.J., Trembath R.C., Viswanathan A.C., Wood N.W., Worrall B.B., Kittner S.J., Mitchell B.D., Kissela B., Meschia J.F., Thijs V., Lindgren A., Macleod M.J., Slowik A., Walters M., Rosand J., Sharma P., Farrall M., Sudlow C.L., Rothwell P.M., Dichgans M., Donnelly P., Markus H.S. Genome-wide association study identifies a variant in $H D A C 9$ associated with large vessel ischemic stroke. Nat. Genet. 2012;44(3):328-333. DOI 10.1038/ng.1081.

Black H.R., Elliott W.J., Neaton J.D., Grandits G., Grambsch P., Grimm R.H., Jr., Hansson L., Lacoucière Y., Muller J., Sleight P., Weber M.A., White W.B., Williams G., Wittes J., Zanchetti A., Fakouhi T.D., Anders R.J. Baseline characteristics and early blood pressure control in the CONVINCE trial. Hypertension. 2001;37(1): 12-18.

Brown R., Whisnant J.P., Sicks J., O’Fallon W.M., Wiebers D.O. Stroke incidence, prevalence, and survival: secular trends in Rochester, Minnesota, through 1989. Stroke. 1996;27(3):373-380.

Burt V.L., Whelton P., Roccella E.J., Brown C., Cutler J.A., Higgins M., Horan M.J., Labarthe D. Prevalence of hypertension in the US adult population results from the Third National Health and Nutrition Examination Survey, 1988-1991. Hypertension. 1995;25(3):305313.

Chen C.C., Yin S.J. Alcohol abuse and related factors in Asia. Int. Rev. Psychiatry. 2008;20(5):425-433. DOI 10.1080/09540260802344075.

Chen K., Xiao Z., Hou S., Zhao R.T., Liu Y.F., Dou H.D., Li G.P., Tao X.M., Li F., Zhou W.Y., Qiu C.C. Strong association between the NINJ2 gene polymorphism and the susceptibility of stroke in Chinese Han population in Fangshan district. Beijing Da Xue Xue Bao. Yi Xue Ban = J. Peking Univ. Health Sci. 2010;42(5):498-502.

Cochrane J., Chen H., Conigrave K.M., Hao W. Alcohol use in China. Alcohol \& Alcoholism. 2003;38(6):537-542.

Crabb D.W. Biological markers for increased risk of alcoholism and for quantitation of alcohol consumption. J. Clin. Invest. 1990;85(2):311315. DOI 10.1172/JCI114439.

Dichgans M. Genetics of ischaemic stroke. Lancet Neurology. 2007; 6(2):149-161. DOI 10.1016/S1474-4422(07)70028-5.

Ding H., Tu X., Xu Y., Xu C., Wang X., Cui G., Bao X., Hui R., Wang Q.K., Wang D.W. No evidence for association of 12p13 SNPs rs11833579 and rs12425791 within NINJ2 gene with ischemic stroke in Chinese Han population. Atherosclerosis. 2011;216(2):381-382. DOI 10.1016/j.atherosclerosis.2011.02.005.

Fields L.E., Burt V.L., Cutler J.A., Hughes J., Roccella E.J., Sorlie P. The burden of adult hypertension in the United States 1999 to 2000 a rising tide. Hypertension. 2004;44(4):398-404. DOI 10.1161/01. HYP.0000142248.54761.56.

Gill J.S., Shipley M.J., Tsementzis S.A., Hornby R.S., Gill S.K., Hitchcock E.R., Beevers D.G. Alcohol consumption - a risk factor for hemorrhagic and non-hemorrhagic stroke. Am. J. Medicine. 1991; 90(1):489-497. 
Gill J.S., Zezulka A.V., Shipley M.J., Gill S.K., Beevers D.G. Stroke and alcohol consumption. N. Engl. J. Med. 1986;315(17):10411046. DOI 10.1056/NEJM198610233151701.

Goldstein L.B., Adams R., Alberts M.J., Appel L.J., Brass L.M., Bushnell C.D., Culebras A., DeGraba T.J., Gorelick P.B., Guyton J.R., Hart R.G., Howard G., Kelly-Hayes M., Nixon J.V., Sacco R.L. Primary prevention of ischemic stroke: A guideline. Stroke. 2006; 37(6):1583-1633. DOI 10.1161/01.STR.0000223048.70103.F1.

Gorelick P.B. Cerebrovascular disease in African Americans. Stroke. 1998;29(12):2656-2564.

Gu J.Y., Li L.W. ALDH2 Glu504Lys polymorphism and susceptibility to coronary artery disease and myocardial infarction in East Asians: a meta-analysis. Arch. Med. Res. 2014;45(1):76-83. DOI 10.1016/j. arcmed.2013.10.002.

Gu L., Su L., Chen Q., Xie J., Yan Y., Wu G., Tan J., Liang B., Dou W., Chen W., Wu P., Wang J., Tang N. Association between the singlenucleotide polymorphism rs12425791 and ischemic stroke in Chinese populations: new data and meta-analysis. Int. J. Neurosci. 2013;123(6):359-365. DOI 10.3109/00207454.2012.761217.

Hasi T., Hao L., Yang L., Su X.L. Acetaldehyde dehydrogenase 2 SNP rs671 and susceptibility to essential hypertension in Mongolians: a case control study. Genet. Mol. Res. 2011;10(1):537-543. DOI 10.4238/vol10-1gmr1056.

Hassan A., Markus H.S. Genetics and ischaemic stroke. Brain. 2000; 123(9):1784-1812. DOI http://dx.doi.org/10.1093/brain/123.9.1784.

Hempel J., Höög J.O., Jörnvall H. Mitochondrial aldehyde dehydrogenase: Homology of putative targeting sequence to that of carbamyl phosphate synthetase I revealed by correlation of cDNA and protein data. FEBS Lett. 1987;222(1):95-98.

Hillbom M., Numminen H., Juvela S. Recent heavy drinking of alcohol and embolic stroke. Stroke. 1999;30(11):2307-2312.

Hu N., Zhang Y., Nair S., Culver B.W., Ren J. Contribution of ALDH2 polymorphism to alcoholism-associated hypertension. Recent Patents on Endocrine, Metabolic \& Immune Drug Discovery. 2014; 8(3):180-185(6).

Huriletemuer H., Zhang C., Niu G., Zhao S., Hurile H. Gene polymorphisms and related risk factors in Mongolian hypertensive stroke patients. Neurosciences. 2010;15(3):184-189.

Ignatieva E.V., Podkolodnaya O.A., Orlov Y.L., Vasiliev G.V., Kolchanov N.A. [Regulatory Genomics: Integrated Experimental and Computer Approaches]. Genetika = Genetics (Moscow). 2015;51(4):409429. DOI 10.7868/S0016675815040062. (in Russian)

Ikram M.A., Seshadri S., Bis J.C., Fornage M., DeStefano A.L., Aulchenko Y.S., Debette S., Lumley T., Folsom A.R., van den Herik E.G., Bos M.J., Beiser A., Cushman M., Launer L.J., Shahar E., Struchalin M., Du Y., Glazer N.L., Rosamond W.D., Rivadeneira F., Kelly-Hayes M., Lopez O.L., Coresh J., Hofman A., DeCarli C., Heckbert S.R., Koudstaal P.J., Yang Q., Smith N.L., Kase C.S., Rice K., Haritunians T., Roks G., de Kort P.L., Taylor K.D., de Lau L.M., Oostra B.A., Uitterlinden A.G., Rotter J.I., Boerwinkle E., Psaty B.M., Mosley T.H., van Duijn C.M., Breteler M.M., Longstreth W.T., Jr., Wolf P.A. Genomewide association studies of stroke. N. Engl. J. Med. 2009;360(17):1718-1728. DOI 10.1056/ NEJMoa0900094.

Izzo J.L., Black H.R., Goodfriend T.L. (Eds.). Hypertension Primer. The Essentials of High Blood Pressure. Third ed. From the Council on High Blood Pressure Research, Am. Heart Assoc. Lippincott Williams \& Wilkins, 2003.

Klatsky A.L., Armstrong M.A., Friedman G.D., Sidney S. Alcohol drinking and risk of hospitalization for ischemic stroke. Am. J. Cardiol. 2001;88(6):703-706.

Komitopoulou A., Platokouki H., Kapsimali Z., Pergantou H., Adamtziki E., Aronis S. Mutations and polymorphisms in genes affecting hemostasis proteins and homocysteine metabolism in children with arterial ischemic stroke. Cerebrovasc. Dis. 2006;22(1):13-20. DOI $10.1159 / 000092332$.

Krupinski J., Kaluza J., Kumar P., Kumar S., Wang J.M. Role of angiogenesis in patients with cerebral ischemic stroke. Stroke. 1994;25(9):1794-1798.
Kurth T., Gaziano J.M., Berger K., Kase C.S., Rexrode K.M., Cook N.R., Buring J.E., Manson J.E. Body mass index and the risk of stroke in men. Arch. Intern. Med. 2002;162(22):2557-2562.

Lai C.L., Liu M.T., Yin S.J., Lee J.T., Lu C.C., Peng G.S. Heavy binge drinking may increase risk of stroke in nonalcoholic hypertensives carrying variant $A L D H 2 * 2$ gene allele. Acta Neurol. Taiwan. 2012; 21(1):39-43

Lai S.M., Alter M., Friday G., Sobel E. A multifactorial analysis of risk factors for recurrence of ischemic stroke. Stroke. 1994;25(5):958-962.

Lewington S., Clarke R., Qizilbash N., Peto R., Collins R. et al. (Prospective Studies Collaboration). Age-specific relevance of usual blood pressure to vascular mortality: a meta-analysis of individual data for one million adults in 61 prospective studies. Lancet. 2002; 360(9349):1903-1913.

Li B.H., Zhang L.L., Yin Y.W., Pi Y., Guo L., Yang Q.W., Gao C.Y., Fang C.Q., Wang J.Z., Li J.C. Association between 12p13 SNPs rs11833579/rs12425791 near NINJ2 gene and ischemic stroke in East Asian population: evidence from a meta-analysis. J. Neurol. Sci. 2012;316(1):116-121. DOI 10.1016/j.jns.2012.01.010.

Li H., Durbin R. Fast and accurate short read alignment with BurrowsWheeler transform. Bioinformatics. 2009;25(14):1754-1760. DOI 10.1093/bioinformatics/btp324

Li H., Handsaker B., Wysoker A., Fennell T., Ruan J., Homer N., Marth G., Abecasis G., Durbin R., 1000 Genome Project Data Processing Subgroup. The Sequence Alignment/Map Format and SAMtools. Bioinformatics. 2009;25(16):2078-2079. DOI 10.1093/bioinformatics/btp352.

Lian G., Yan Y., Jianxiong L., Juanjuan X., Qing C., Guangliang W., $\mathrm{Li}$ S. The rs11833579 and rs12425791 polymorphisms and risk of ischemic stroke in an Asian population: a meta-analysis. Thromb. Res. 2012;130(3):e95-e102. DOI 10.1016/j.thromres.2012.06.014.

Lindsberg P.J., Grau A.J. Inflammation and infections as risk factors for ischemic stroke. Stroke. 2003;34(10):2518-2532. DOI 10.1161/01. STR.0000089015.51603.CC.

Matar N.M., Brown W.M., Scholz S., Simón-Sánchez J., Fung H.C., Hernandez D., Gibbs J.R., De Vrieze F.W., Crews C., Britton A., Langefeld C.D., Brott T.G., Brown R.D., Jr., Worrall B.B., Frankel M., Silliman S., Case L.D., Singleton A., Hardy J.A., Rich S.S., Meschia J.F. A genome-wide genotyping study in patients with ischaemic stroke: initial analysis and data release. Lancet Neurol. 2007;6(5):414-420. DOI 10.1016/S1474-4422(07)70081-9.

Mazzaglia G., Britton A.R., Altmann D.R., Chenet L. Exploring the relationship between alcohol consumption and non-fatal or fatal stroke: a systematic review. Addiction. 2001;96(12):1743-1756. DOI 10.1080/09652140120089490.

Mizuno Y., Harada E., Morita S., Kinoshita K., Hayashida M., Shono M., Morikawa Y., Murohara T., Nakayama M., Yoshimura M., Yasue H. East Asian variant of aldehyde dehydrogenase 2 is associated with coronary spastic angina: possible roles of reactive aldehydes and implications of alcohol flushing syndrome. Circulation. 2015;131(19):1665-1673. DOI 10.1161/CIRCULATIONAHA.114. 013120 .

Morozova M.V., Popova N.K. Effect of alcohol in combination with stress in the prenatal period on adult mice behaviour. Rossiyskiy fiziologicheskiy zhurnal im. I.M. Sechenova = I.M. Sechenov Physiological Journal. 2010;96(11):1114-1121. (in Russian)

Mozaffarian D., Benjamin E.J., Go A.S., Arnett D.K., Blaha M.J., Cushman M., Das S.R., de Ferranti S., Després J.P., Fullerton H.J., Howard V.J., Huffman M.D., Isasi C.R., Jiménez M.C., Judd S.E., Kissela B.M., Lichtman J.H., Lisabeth L.D., Liu S., Mackey R.H., Magid D.J., McGuire D.K., Mohler E.R. 3rd, Moy C.S., Muntner P., Mussolino M.E., Nasir K., Neumar R.W., Nichol G., Palaniappan L., Pandey D.K., Reeves M.J., Rodriguez C.J., Rosamond W., Sorlie P.D., Stein J., Towfighi A., Turan T.N., Virani S.S., Woo D., Yeh R.W., Turner M.B. Heart Disease and Stroke Statistics-2016 Update: A Report from the American Heart Association. Circulation. 2016;133(4):447-454. DOI 10.1161/CIR.0000000000000366.

Muglia P., Tozzi F., Galwey N.W., Francks C., Upmanyu R., Kong X.Q., Antoniades A., Domenici E., Perry J., Rothen S., Vandeleur C.L., 
Mooser V., Waeber G., Vollenweider P., Preisig M., Lucae S., Müller-Myhsok B., Holsboer F., Middleton L.T., Roses A.D. Genomewide association study of recurrent major depressive disorder in two European case-control cohorts. Mol. Psychiatry. 2010;15(6):589601. DOI 10.1038/mp.2008.131.

Nabodita K., Sher A. Genes, genetics, and environment in type 2 diabetes: Implication in personalized medicine. DNA and Cell Biology. 2016;35(1):1-12. DOI 10.1089/dna.2015.2883.

Ong K.L., Cheung B.M., Man Y.B., Lau C.P., Lam K.S. Prevalence, awareness, treatment, and control of hypertension among United States adults 1999-2004. Hypertension. 2007;49(1):69-75. DOI 10.1161/01.HYP.0000252676.46043.18.

Orlov Y.L. Computer-assisted study of the regulation of eukaryotic gene transcription on the base of data on chromatin sequencing and immunoprecipitation. Vavilovskii Zhurnal Genetiki i Selektsii = Vavilov Journal of Genetics and Breeding. 2014;18(1):193206. (in Russian)

Orlov Y.L., Baranova A.V., Markel A.L. Computational models in genetics at BGRS $\backslash$ SB-2016: introductory note. BMC Genetics. 2016; 17(3):465. DOI 10.1186/s12863-016-0465-3.

Rexrode K.M., Hennekens C.H., Willett W.C., Colditz G.A., Stampfer M.J., Rich-Edwards J.W., Speizer F.E., Manson J.E. A prospective study of body mass index, weight change, and risk of stroke in women. JAMA. 1997;277(19):1539-1545.

Rubattu S., Di Angelantonio E., Stanzione R., Zanda B., Evangelista A., Pirisi A., De Paolis P., Cota L., Brunetti E., Volpe M. Gene polymorphisms of the renin-angiotensin-aldosterone system and the risk of ischemic stroke: a role of the A1166C/AT1 gene variant. J. Hypertens. 2004;22(11):2129-2134.

Sacco R.L., Boden-Albala B., Gan R., Chen X., Kargman D.E., Shea S., Paik M.C., Hauser W.A. Stroke incidence among white, black, and Hispanic residents of an urban community the Northern Manhattan Stroke Study. Am. J. Epidemiol. 1998;147(3):259-268.

Shi J., Levinson D.F., Duan J., Sanders A.R., Zheng Y., Pe'er I., Dudbridge F., Holmans P.A., Whittemore A.S., Mowry B.J., Olincy A., Amin F., Cloninger C.R., Silverman J.M., Buccola N.G., Byerley W.F., Black D.W., Crowe R.R., Oksenberg J.R., Mirel D.B., Kendler K.S., Freedman R., Gejman P.V. Common variants on chromosome 6p22.1 are associated with schizophrenia. Nature. 2009; 460(7256):753-757. DOI 10.1038/nature08192.

Smith M. Genetics of human alcohol and aldehyde dehydrogenases. Adv. Hum. Genet. 1986;15:249-290.

Song Y.-M., Sung J., Smith G.D., Ebrahim S. Body mass index and ischemic and hemorrhagic stroke: A prospective study in Korean men. Stroke. 2004;35(4):831-836. DOI 10.1161/01.STR.0000119386.22691.1C.

Tiis R.P., Osipova L.P., Churkina T.V., Tabikhanova L.E., Lichman D.V., Voronina E.N., Filipenko M.L. The ILE462VAL polymorphism of the cytochrome P450 CYP1A1 gene among Tundra Nenets in Ya-
malo-Nenets Autonomous Okrug, Nganasans in the Taimyr Peninsula and Russians in Siberia. Vavilovskii Zhurnal Genetiki i Selektsii = Vavilov Journal of Genetics and Breeding. 2016;20(1):16-22. DOI 10.18699/VJ16.102. (in Russian)

Tong Y., Zhang Y., Zhang R., Geng Y., Lin L., Wang Z., Liu J., Li X., Cao Z., Xu J., Chai Y., Fan H., Hu F.B., Lu Z., Cheng J. Association between two key SNPs on chromosome 12p13 and ischemic stroke in Chinese Han population. Pharmacogenet. Genom. 2011;21(9):572578. DOI 10.1097/FPC.0b013e32834911d0.

Wan X.H., Li S.J., Cheng P., Zhang Q., Yang X.C., Zhong G.Z., $\mathrm{Hu}$ W.L., Jin L., Wang X.F. NINJ2 polymorphism is associated with ischemic stroke in Chinese Han population. J. Neurol. Sci. 2011; 308(1):67-71. DOI 10.1016/j.jns.2011.06.011.

Wang Y., Mi J., Shan X.Y., Wang Q.J., Ge K.Y. China facing an obesity epidemic and the consequences? The trends in obesity and chronic disease in China. Int. J. Obesity (Lond). 2007;31(1):177-188. DOI 10.1038/sj.ijo.0803354.

Wang Y., Zhang Y., Zhang J., Tang X., Qian Y., Gao P., Zhu D. Association of a functional single-nucleotide polymorphism in the $A L D H 2$ gene with essential hypertension depends on drinking behavior in a Chinese Han population. J. Hum. Hypertens. 2013;27(3):181-186. DOI 10.1038/jhh.2012.15

Whelton P.K., He J., Appel L.J., Cutler J.A., Havas S., Kotchen T.A., Roccella E.J., Stout R., Vallbona C., Winston M.C., Karimbakas J. Primary prevention of hypertension: clinical and public health advisory from the National High Blood Pressure Education Program. JAMA. 2002;288(15):1882-1888. DOI 10.1001/jama.288.15.1882.

Wolf P.A., D’Agostino R.B., O’Neal M.A., Sytkowski P., Kase C.S., Belanger A.J., Kannel W.B. Secular trends in stroke incidence and mortality. The Framingham Study. Stroke. 1992;23(11):1551-1555.

Xie J.J., Gu L., Chen Q., Wu G.L., Yan Y., Su L. Correlation study on 12p13 single nucleotide polymorphism rs12425791 and Chinese medical syndrome types in ischemic stroke patients of the Han nationality. Zhongguo Zhong Xi Yi Jie He Za Zhi = Chinese J. Integrated Traditional and Western Medicine. 2013;33(1):47-50.

Yao C.T., Cheng C.A., Wang H.K., Chiu S.W., Chen Y.C., Wang M.F., Yin S.J., Peng G.S. The role of $A L D H 2$ and $A D H 1 B$ polymorphism in alcohol consumption and stroke in Han Chinese. Hum. Genomics. 2011;5(6):569-576.

Yokoyama A., Mizukami T., Matsui T., Yokoyama T., Kimura M., Matsushita S., Higuchi S., Maruyama K. Genetic polymorphisms of alcohol dehydrogenase-1B and aldehyde dehydrogenase-2 and liver cirrhosis, chronic calcific pancreatitis, diabetes mellitus, and hypertension among Japanese alcoholic men. Alcohol.: Clin. Exp. Res. 2013;37(8):1391-1401. DOI 10.1111/acer.12108.

Zhang Z., Xu G., Wei Y., Zhu W., Fan X., Liu X. Impact of chromosome 12p13 variants on ischemic stroke risk. Int. J. Neurosci. 2016; 126(9):856-862. DOI 10.3109/00207454.2015.1079710. 